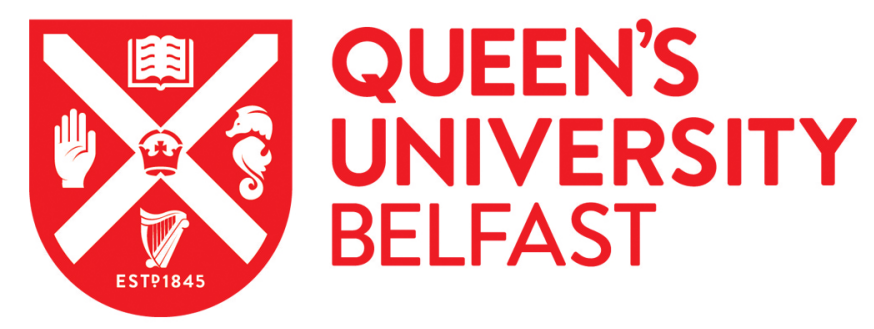

\title{
Effect of supplementation with $B$ vitamins and antioxidants on levels of asymmetric dimethylarginine (ADMA) and C-reactive protein (CRP): a double-blind, randomised, factorial design, placebo-controlled trial.
}

O'Doherty, M., Gilchrist, S., Young, I., McKinley, M., Yarnell, J., Gey, K. F., Evans, A., Skidmore, P. M., \& Woodside, J. (2010). Effect of supplementation with B vitamins and antioxidants on levels of asymmetric dimethylarginine (ADMA) and C-reactive protein (CRP): a double-blind, randomised, factorial design, placebocontrolled trial. European Journal of Nutrition, 49(8), 483-492. https://doi.org/10.1007/s00394-010-0107-x

\section{Published in:}

European Journal of Nutrition

Queen's University Belfast - Research Portal:

Link to publication record in Queen's University Belfast Research Portal

\section{General rights}

Copyright for the publications made accessible via the Queen's University Belfast Research Portal is retained by the author(s) and / or other copyright owners and it is a condition of accessing these publications that users recognise and abide by the legal requirements associated with these rights.

Take down policy

The Research Portal is Queen's institutional repository that provides access to Queen's research output. Every effort has been made to ensure that content in the Research Portal does not infringe any person's rights, or applicable UK laws. If you discover content in the Research Portal that you believe breaches copyright or violates any law, please contact openaccess@qub.ac.uk. 


\title{
Effect of supplementation with B vitamins and antioxidants on levels of asymmetric dimethylarginine (ADMA) and C-reactive protein (CRP): a double-blind, randomised, factorial design, placebo-controlled trial
}

\author{
Mark G. O'Doherty - Sarah E. C. M. Gilchrist • Ian S. Young • \\ Michelle C. McKinley • John W. G. Yarnell • K. Fred Gey • Alun Evans • \\ Paula M. L. Skidmore • Jayne V. Woodside
}

Received: 1 December 2009/Accepted: 1 April 2010/Published online: 18 April 2010

(C) Springer-Verlag 2010

\begin{abstract}
Purpose Cardiovascular risk factors such as elevated levels of asymmetric dimethylarginine (ADMA)/C-reactive protein (CRP) and homocysteine are potentially related to essential micronutrients such as certain B vitamins and antioxidant vitamins. The aim of the present study was to investigate whether supplementation with moderate doses of $\mathrm{B}$ vitamins and/or antioxidants could alter either ADMA and/or CRP concentrations in middle-aged, apparently healthy men with mildly elevated homocysteine levels.

Methods A randomised, double-blind, factorial design, intervention study was carried out on 132 men with mildly elevated homocysteine levels, allocated to four groups (a) B vitamins alone $-1 \mathrm{mg}$ folic acid, $7.2 \mathrm{mg}$ pyridoxine, $0.02 \mathrm{mg}$ cyanocobalamin daily, (b) antioxidants alone$150 \mathrm{mg}$ ascorbic acid, $67 \mathrm{mg}$ vitamin $\mathrm{E}, 9 \mathrm{mg} \beta$-carotene daily, (c) B vitamins with antioxidant vitamins, or (d) placebo. A total of 101 men completed the study to 8 weeks.
\end{abstract}

M. G. O’Doherty - S. E. C. M. Gilchrist .

I. S. Young · M. C. McKinley · J. W. G. Yarnell · A. Evans ·

J. V. Woodside

School of Medicine, Dentistry and Biomedical Sciences,

Queen's University, Belfast, UK

K. F. Gey

Vitamin Research Unit, University of Berne,

Berne, Switzerland

P. M. L. Skidmore

University of Otago, Dunedin, New Zealand

M. G. O'Doherty ( $\square)$

Cancer Epidemiology Health Services Research Group,

Centre for Public Health, Queens University Belfast,

Mulhouse Building, Royal Victoria Hospital,

Grosvenor Road, Belfast BT12 6BJ, UK

e-mail: m.odoherty@qub.ac.uk
Results When the percentage of baseline ADMA and CRP was examined at 8 weeks, no statistically significant differences were observed between the four groups $(p=0.21$ and $p=0.90$, respectively). Similar non-significant results were observed when analysis was stratified based on baseline CRP levels $(<1.0 \mathrm{mg} / \mathrm{L}, p=0.10$; $\geq 1.0 \mathrm{mg} / \mathrm{L}, p=0.64$ ) and smoking status (all $p \geq 0.05$ ). Conclusions Supplementation with moderate doses of B vitamins and/or antioxidants did not alter either ADMA or CRP concentrations in these middle-aged, apparently healthy men with mildly elevated homocysteine levels.

Keywords Asymmetric dimethylarginine .

C-reactive protein - Cardiovascular disease .

Homocysteine $\cdot$ B vitamins - Antioxidant vitamins

\section{Introduction}

Evidence indicates a central role for the endothelium and inflammation in all phases of atherosclerosis. Therefore, a reduction in inflammatory levels and improvement in endothelial function by traditional and novel treatment strategies, such as micronutrients, may lead to a reduction in cardiovascular events.

Increased ADMA, an endogenous inhibitor of nitric oxide synthase, has been observed in subjects with cardiovascular disease (CVD) [1-3], where it results in reduced nitric oxide bioavailability, leading to endothelial dysfunction and CVD [4, 5]. Therapies that lower ADMA and reduce endothelial dysfunction may therefore reduce CVD risk.

Knowledge of ADMA synthesis and metabolism reveals a potential for antioxidants to lower ADMA. ADMA is synthesised when arginine residues in proteins are 
methylated by the action of protein arginine $N$-methyltransferases (PRMTs) [6]. PRMT 1 is involved in the production of ADMA and is expressed in the heart, vascular smooth muscle cells and endothelial cells [6]. Once the proteins are hydrolysed, free methylated arginines are released into the cytosol. ADMA is excreted in the urine to some extent, but the major metabolic pathway is by degradation by the enzyme dimethylarginine dimethylaminohydrolase (DDAH) [6]. Consequently, whereas impaired renal function may result in elevated levels of ADMA, attenuation of DDAH activity may play the key role in increasing ADMA levels in persons without renal complications [7]. Therefore, the attenuation of DDAH activity by oxidative stress [8], whereby a cysteine molecule held in an activated state in the tertiary structure of the enzyme is inactivated by oxidation, may lead to an accumulation of ADMA. Antioxidants have been shown to decrease ADMA levels in cultured human endothelial cells [9] and in vivo rats exposed to native low-density lipoprotein [10]. Consequently, antioxidant therapy may reduce ADMA levels by attenuating the effects of oxidative stress.

Subjects with hyperhomocysteinaemia have also been shown to have elevated ADMA concentrations [11, 12]. Therefore, as homocysteine (tHcy) is lowered through B vitamin supplementation [13], such treatment may also lead to a reduction in ADMA levels.

A large body of evidence also indicates a central role for inflammation in atherosclerotic disease [14, 15]. Multiple epidemiological studies have associated C-reactive protein (CRP), an acute-phase reactant and marker of inflammation, with CVD risk [16]. CRP is synthesised predominately by hepatocytes in the liver in response to interleukin-6 (IL-6), an inflammatory cytokine, which is secreted during acute injury [17]. As for ADMA, therapies that lower CRP as a marker of inflammation may therefore be expected to reduce CVD risk. A number of studies have suggested that antioxidant supplementation may lower CRP [18-23], but this is not always consistent [24-30]. Similarly, increasing levels of tHcy in cell cultures seems to promote IL- 6 production by monocytes [31] and endothelial cells [32] and, therefore, B vitamins may also reduce $\mathrm{CRP}$ as a result of their tHcy-lowering potential.

Evidence, therefore, indicates that both B vitamins and antioxidants have the potential to reduce ADMA and CRP concentrations as biomarkers of CVD risk. To our knowledge, no intervention studies have yet investigated the effects of B vitamins and antioxidants, both independently and combined, on both ADMA and CRP levels. We have performed a randomised, double-blind, factorial design, intervention study to investigate whether supplementation with B vitamins and/or antioxidants could alter ADMA and/or CRP concentrations in middle-aged, apparently healthy men with mildly elevated tHcy levels. In addition, we tested whether or not the treatment effect depended on baseline CRP levels and smoking status.

\section{Materials and methods}

\section{Subjects and study design}

This intervention study was originally designed to test the effect of B vitamins and antioxidant vitamins on tHcy concentrations in men with mildly elevated tHcy levels, and the results have previously been published [13]. Therefore, the analyses reported here represent analyses of secondary endpoints.

Briefly, participants were male volunteers aged 30-49 from a single, large, Belfast-based workforce and included all grades of staff from manual to clerical to administrative. The men completed a dietary questionnaire before attending a clinic, at which time a brief medical history was taken and height and weight were determined. Blood pressure was recorded with an automated sphygmomanometer on the right arm, and a fasting venous blood sample was then taken from the left arm. A sample anticoagulated with EDTA was used to provide plasma for tHcy analysis and another sample provided serum for vitamin analysis. The EDTA treated blood samples were processed within $15 \mathrm{~min}$ of venepuncture whereas the serum samples were kept in the dark and returned to the laboratory for processing. Those who were diabetic, who had received a general anaesthetic within the past 3 months, or who were taking any form of dietary supplementation were excluded from further study (these factors are known to affect tHcy).

\section{Intervention design}

Overall, tHcy was measured in 509 eligible subjects. Men who had tHcy concentrations in the upper third of the distribution were targeted for the intervention study and invited to re-attend by letter $(n=152)$. Of the 152 men chosen for intervention, $132(87 \%)$ were willing to participate. Those who decided to take part had another blood sample taken for baseline measurements. One sample was anticoagulated with EDTA or heparin or left to clot as before. A sample of whole blood was stabilised with EDTA and dithiothreitol, separated and stored in 5\% MPA for vitamin C (ascorbic acid) analysis [33]. At this point, the men were randomly allocated in a double-blind fashion in balanced blocks of eight subjects to four groups (a) B vitamins alone-1 $\mathrm{mg}$ folic acid, $7.2 \mathrm{mg}$ pyridoxine, $0.02 \mathrm{mg}$ cyanocobalamin daily, (b) antioxidants alone-150 mg ascorbic acid, $67 \mathrm{mg}$ vitamin $\mathrm{E}, 9 \mathrm{mg} \beta$-carotene daily, (c) $\mathrm{B}$ vitamins with antioxidant vitamins, or (d) placebo. Doses of micronutrients were selected based on a consideration of the original 
primary endpoints. Blinding was carried out in the form of colour coding, and the code was not broken until all analyses had been carried out.

Each subject was given a 4-week supply of low-energy chocolates containing one of the four vitamin combinations outlined above (Sandoz Nutrition Ltd, Berne, Switzerland). Four weeks later, fasting blood samples were taken and subjects were given vitamin supplements for a further 4 weeks. After this period (total of 8 weeks) further fasting blood samples were obtained. Recruitment took place in three phases between January 1995 and March 1995, i.e. in the lowest seasonal supply of vitamin $\mathrm{C}$ and therefore possibly co-existing vitamins. The sample size of 25 subjects per group was sufficient to give the study $90 \%$ power to detect a statistically significant $(p<0.05) 20 \%$ reduction in tHcy concentrations for either of the two interventions.

This study was approved by the Research Ethics Committee of the Faculty of Medicine, Dentistry and Biomedical Sciences, Queen's University Belfast who followed the guidelines of the Royal College of Physicians of London. Informed consent was obtained from all subjects for the study.

\section{Laboratory methods}

Total tHcy, both free and protein-bound, was assayed by HPLC [34]. Serum total cholesterol was estimated using an enzymatic CHOD-PAP kit, while serum triglycerides were measured using the Peridochrom GPO-PAP kit (both Boehringer Mannheim, Germany (now Roche Applied Science)). All cholesterol assays were carried out on the Cobas Fara auto-analyser. Plasma vitamin $\mathrm{B}_{12}$ (cobalamin) and folate concentrations were measured by competitive protein binding utilised by the SimulTRAC-SNB radioassay kit (ICN Pharmaceuticals, California, USA). Concentrations of serum vitamin $\mathrm{E}$ ( $\alpha$-tocopherol) and $\beta$-carotene were measured by HPLC $[35,36]$. Vitamin $C$ was measured on a Cobas FARA centrifugal analyser with a fluorescent attachment [33]. The active form of vitamin $\mathrm{B}_{6}$, pyridoxal5-phosphate, was quantified in serum using a HPLC method [37]. Plasma CRP was determined using an ultra sensitive assay (Biokit, Barcelona, Spain) on the ILab 600 Chemistry System (Instrumentation Laboratory, Cheshire, UK). ADMA along with symmetrical dimethylarginine, arginine and homoarginine were assayed by HPLC [38]. All assays were externally quality assured, and in-house quality control samples were also included in every run.

\section{Statistical analysis}

Continuous variables were checked for normality and were logarithmically transformed where necessary. Data are presented as mean $(95 \% \mathrm{CI})$ or geometric mean $(95 \% \mathrm{CI})$ where indicated. Chi-square statistics were carried out on categorical variables, such as comparing smoking status in the four intervention groups. The four intervention groups were compared on baseline characteristics such as tHcy and vitamin concentrations using one-way analysis of variance (ANOVA) followed by a Student-Neuman-Keuls multiple-range test. The effect of intervention on the change in each endpoint of interest was compared between the four intervention groups using ANOVA, and smokers were compared to non-smokers with regard to baseline CRP and ADMA concentrations using the independent samples $t$ test. $p<0.05$ was used as the threshold for significance. Pearson correlation coefficients were calculated to estimate colinearity between baseline vitamin status with ADMA and CRP.

Individuals with raised CRP levels ( $>10 \mathrm{mg} / \mathrm{L})$ were excluded from statistical analyses. This cut point was selected based on guidelines issued by the Centers for Disease Control and the American Heart Association for the use CRP in clinical and public health practice [15]; CRP concentrations of $>10 \mathrm{mg} / \mathrm{L}$ represented acute infection or inflammatory disease, possibility from a non-cardiovascular origin. All analyses were performed with the use of SPSS 14.0 for Windows (SPSS Inc, Chicago, USA).

\section{Results}

tHcy was measured in 509 eligible subjects, of which 152 were targeted for the intervention study based on the inclusion criteria (tHcy concentrations in the upper third of the distribution). Of the 152 men chosen for intervention, $132(87 \%)$ were willing to participate. A total of 101 men completed the study to 8 weeks.

Baseline ADMA was inversely associated with baseline folate $(r=-0.282, p=0.005)$, vitamin $\mathrm{C}(r=-0.212$, $p=0.038)$ and $\alpha$-carotene $(r=-0.217, p=0.034)$ concentrations, whilst CRP was inversely associated with $\beta$-carotene concentrations only $(r=-0.216, p=0.031)$.

There was no significant difference between the four groups at baseline (indicating randomisation was successful) with the exception of systolic blood pressure which was significantly lower in the group receiving B vitamins ( $p=0.03$ ) compared with the other three groups (Table 1).

Baseline vitamin status and values after 8 weeks of supplementation in the four groups are shown in Table 2. Supplementation for 8 weeks with B vitamins increased plasma folate, pyridoxal-5-phosphate and vitamin $\mathrm{B}_{12}$ status significantly, which resulted in an expected, concomitant, lowering in plasma tHcy [13]. As expected, the antioxidant supplementation significantly improved the initially poor plasma vitamin $\mathrm{C}$ status and also significantly 
Table 1 Baseline characteristics of intervention subjects

\begin{tabular}{|c|c|c|c|c|}
\hline & Placebo & B vitamins & Antioxidants & $\mathrm{B}+$ antioxidants \\
\hline$n$ & 33 & 32 & 33 & 34 \\
\hline Age (years) & $38.9(36.9,40.9)$ & $39.3(37.0,41.6)$ & $40.1(37.8,42.4)$ & $40.6(38.2,42.9)$ \\
\hline BMI $\left(\mathrm{kg} / \mathrm{m}^{2}\right)$ & $25.6(24.6,26.6)$ & $26.1(25.0,27.1)$ & $26.5(25.5,27.1)$ & $26.7(25.4,28.1)$ \\
\hline Systolic blood pressure $(\mathrm{mm} \mathrm{Hg}) *$ & $129(125,134)$ & $122(118,127)$ & $130(125,136)$ & $132(127,136)$ \\
\hline Diastolic blood pressure $(\mathrm{mm} \mathrm{Hg})$ & $81(78,84)$ & $78(75,82)$ & $82(80,85)$ & $83(79,87)$ \\
\hline Cholesterol (mmol/L) & $5.6(5.1,6.0)$ & $5.6(5.2,5.9)$ & $6.0(5.6,6.4)$ & $6.1(5.7,6.5)$ \\
\hline Triglycerides $(\mathrm{mmol} / \mathrm{L})$ & $1.44(1.22,1.69)$ & $1.34(1.14,1.58)$ & $1.65(1.40,1.93)$ & $1.56(1.32,1.85)$ \\
\hline Smoking (\% smokers $)^{\mathrm{a}}$ & 27.3 & 18.8 & 15.2 & 29.4 \\
\hline
\end{tabular}

Mean $(95 \% \mathrm{CI})$, except triglycerides given as geometric mean $(95 \% \mathrm{CI})$

$* p=0.03$ for difference between the four intervention groups. One-way ANOVA except ${ }^{\mathrm{a}} \mathrm{Chi}$-square

Table 2 Baseline and post-supplementation plasma total homocysteine and vitamin concentrations

\begin{tabular}{|c|c|c|c|c|}
\hline & Placebo & B vitamins & Antioxidants & $\mathrm{B}+$ antioxidants \\
\hline \multicolumn{5}{|l|}{$n$} \\
\hline Week 0 & 33 & 32 & 33 & 34 \\
\hline Week 8 & 26 & 22 & 25 & 28 \\
\hline \multicolumn{5}{|c|}{ Homocysteine $(\mu \mathrm{mol} / \mathrm{L})$} \\
\hline Week 0 & $9.22(8.46,10.04)$ & $9.12(8.22,10.11)$ & $8.78(7.77,9.91)$ & $10.31(8.85,12.00)$ \\
\hline Week 8 & $8.69(7.91,9.55)$ & $6.67 *(6.20,7.17)$ & $8.70(7.64,9.91)$ & $7.49 *(6.33,8.87)$ \\
\hline \multicolumn{5}{|c|}{ Folate (nmol/L) } \\
\hline Week 0 & $10.04(8.81,11.43)$ & $9.53(8.40,10.81)$ & $11.86(10.07,13.96)$ & $9.50(8.24,10.96)$ \\
\hline Week 8 & $10.51(8.96,12.31)$ & $29.67 *(23.67,37.21)$ & $14.14(11.76,16.99)$ & $34.25 *(27.79,42.18)$ \\
\hline \multicolumn{5}{|c|}{ Vitamin $\mathrm{B}_{12}(\mathrm{pmol} / \mathrm{L})$} \\
\hline Week 0 & $264(228,305)$ & $243(208,285)$ & $270(236,307)$ & $267(231,308)$ \\
\hline Week 8 & $253(216,298)$ & $382 *(326,449)$ & $267(227,314)$ & $368 *(313,433)$ \\
\hline \multicolumn{5}{|c|}{ Pyridoxal-5-phosphate (nmol/L) } \\
\hline Week 0 & $34.4(26.9,44.0)$ & $33.7(26.1,43.4)$ & $33.4(24.7,45.1)$ & $46.1(33.3,63.9)$ \\
\hline Week 8 & $45.6(35.4,58.7)$ & $72.4 *(58.2,90.1)$ & $34.4(26.2,45.3)$ & $117.3 *(89.2,154.2)$ \\
\hline \multicolumn{5}{|c|}{ Vitamin $C(\mu \mathrm{mol} / \mathrm{L})$} \\
\hline Week 0 & $20.7(15.2,28.2)$ & $18.2(12.3,27.0)$ & $19.2(14.1,26.1)$ & $22.9(16.9,30.9)$ \\
\hline Week 8 & $23.3(16.2,33.5)$ & $16.1(9.7,26.8)$ & $52.1 * *(45.4,60.1)$ & $49.8 * *(42.8,58.1)$ \\
\hline \multicolumn{5}{|c|}{ Vitamin $E(\mu \mathrm{mol} / \mathrm{L})$} \\
\hline Week 0 & $26.3(23.5,29.3)$ & $26.2(23.6,29.2)$ & $29.2(25.9,33.0)$ & $31.0(27.1,35.5)$ \\
\hline Week 8 & $29.0(25.4,33.0)$ & $29.2(25.8,33.0)$ & $44.7 * *(38.7,51.8)$ & $45.7 * *(40.2,52.0)$ \\
\hline \multicolumn{5}{|c|}{ Lipid standardised vitamin $\mathrm{E}(\mu \mathrm{mol} / \mathrm{L})$} \\
\hline Week 0 & $26.4(23.5,29.7)$ & $26.7(23.9,29.9)$ & $27.2(24.7,29.9)$ & $28.6(25.8,31.8)$ \\
\hline Week 8 & $29.3(26.3,32.6)$ & $30.6(27.3,34.3)$ & $39.5^{* *}(34.7,45.0)$ & $42.9 *(38.7,47.6)$ \\
\hline \multicolumn{5}{|c|}{$\beta$-carotene $(\mu \mathrm{mol} / \mathrm{L})$} \\
\hline Week 0 & $0.180(0.130,0.233)$ & $0.175(0.120,0.233)$ & $0.170(0.121,0.221)$ & $0.210(0.136,0.290)$ \\
\hline Week 8 & $0.198(0.148,0.250)$ & $0.238(0.131,0.355)$ & $1.339 * *(0.930,1.836)$ & $1.343 * *(0.940,1.829)$ \\
\hline
\end{tabular}

Geometric mean $(95 \% \mathrm{CI})$

$* p<0.01$ significantly different from placebo and antioxidants groups. One-way ANOVA

** $p<0.01$ significantly different from placebo and B vitamins groups. One-way ANOVA 
increased vitamin $\mathrm{E}$ and $\beta$-carotene status [39]. Nevertheless, despite expected improvements in nutrient status, supplementation with $\mathrm{B}$ vitamins and/or antioxidants had no significant effect on the ADMA or CRP concentrations ( $p=0.21$ and $p=0.90$, respectively) (Table 3 ).

This analysis also tested whether the treatment effect depended on baseline CRP levels (Table 4). Among those with baseline CRP $<1.0 \mathrm{mg} / \mathrm{L}$, no statistically significant difference was observed between the four groups $(p=0.10)$ when the percentage of baseline CRP was examined at 8 weeks. Among those with increased CVD risk, as represented by $\mathrm{CRP} \geq 1.0 \mathrm{mg} / \mathrm{L}$, when the percentage of baseline CRP was examined at 8 weeks, again no statistically significant difference was observed between the four groups $(p=0.64)$.

Because of the baseline associations described above, analyses were carried out to determine whether B vitamins and/or antioxidants resulted in a change in ADMA or CRP concentrations depending on whether subjects initially had low concentrations of baseline folate $(<7 \mathrm{nmol} / \mathrm{L})$; [40], vitamin C $(\leq 22.7 \mu \mathrm{mol} / \mathrm{L})$; [39], or $\alpha$-carotene $(<0.1 \mu \mathrm{mol} / \mathrm{L}) ; \quad[41]$ for ADMA; and $\beta$-carotene

Table 3 Percentage of baseline plasma ADMA and CRP (excludes subjects with CRP $>10 \mathrm{mg} / \mathrm{L}$ ) concentrations after 8 weeks of intervention

\begin{tabular}{llllr}
\hline Intervention group & $n$ & $\begin{array}{l}\text { Baseline ADMA } \\
(\mu \mathrm{mol} / \mathrm{L})\end{array}$ & $\begin{array}{l}\text { Post-intervention } \\
\text { ADMA }(\mu \mathrm{mol} / \mathrm{L})\end{array}$ & $\begin{array}{r}\text { Percentage of baseline } \\
\text { ADMA at } 8 \text { weeks* }\end{array}$ \\
\hline Placebo & 26 & $0.89(0.75,1.05)$ & $0.87(0.74,1.01)$ & $98(94,103)$ \\
B vitamins & 22 & $0.85(0.74,0.98)$ & $0.87(0.77,1.02)$ & $102(95,107)$ \\
Antioxidants & 22 & $0.79(0.57,1.08)$ & $0.73(0.57,0.95)$ & $92(74,106)$ \\
B + antioxidants & 25 & $0.86(0.70,1.02)$ & $0.88(0.65,1.09)$ & $99(90,110)$ \\
\hline Intervention group & $n$ & Baseline CRP & Post-intervention & Percentage of baseline \\
& & $(\mathrm{mg} / \mathrm{L})$ & CRP (mg/L) & CRP at 8 weeks** \\
\hline Placebo & 26 & $1.11(0.77,1.40)$ & $1.22(0.86,1.59)$ & $110(92,145)$ \\
B vitamins & 20 & $1.15(0.87,1.36)$ & $1.19(0.83,1.76)$ & $103(82,117)$ \\
Antioxidants & $1.37(0.94,1.51)$ & $1.49(1.02,1.95)$ & $109(92,137)$ \\
B + antioxidants & 23 & $1.31(0.83,1.89)$ & $1.52(0.90,2.43)$ & $116(92,137)$
\end{tabular}

Geometric mean (interquartile range)

$* p=0.21$ for differences in percentage of baseline ADMA between the four groups after 8 weeks. One-way ANOVA

** $p=0.90$ for differences in percentage of baseline CRP between the four groups after 8 weeks. One-way ANOVA

Table 4 Percentage of baseline plasma CRP concentrations after 8 weeks of intervention (stratified by baseline CRP and excludes subjects with $\mathrm{CRP}>10 \mathrm{mg} / \mathrm{L})$

\begin{tabular}{|c|c|c|c|c|}
\hline Intervention group & $n$ & $\begin{array}{l}\text { Baseline CRP for } \\
\text { subjects with } \\
\mathrm{CRP}<1.0 \mathrm{mg} / \mathrm{L}\end{array}$ & $\begin{array}{l}\text { Post-intervention } \\
\mathrm{CRP} \text { for subjects } \\
\text { with } \mathrm{CRP}<1.0 \mathrm{mg} / \mathrm{L} \\
\text { at baseline }\end{array}$ & $\begin{array}{l}\text { Percentage of } \\
\text { baseline CRP at } \\
8 \text { weeks* }\end{array}$ \\
\hline Placebo & 13 & $0.78(0.69,0.92)$ & $0.92(0.78,0.99)$ & $119(100,136)$ \\
\hline B vitamins & 9 & $0.84(0.75,0.96)$ & $0.85(0.69,1.03)$ & $102(84,115)$ \\
\hline Antioxidants & 10 & $0.89(0.82,0.97)$ & $1.32(0.86,1.92)$ & $148(101,207)$ \\
\hline $\mathrm{B}+$ Antioxidants & 13 & $0.82(0.72,0.91)$ & $0.94(0.66,1.21)$ & $114(92,129)$ \\
\hline Intervention group & $n$ & $\begin{array}{l}\text { Baseline CRP for } \\
\text { subjects with } \\
\mathrm{CRP} \geq 1.0 \mathrm{mg} / \mathrm{L}\end{array}$ & $\begin{array}{l}\text { Post-intervention } \\
\text { CRP for subjects } \\
\text { with } \mathrm{CRP} \geq 1.0 \mathrm{mg} / \mathrm{L} \\
\text { at baseline }\end{array}$ & $\begin{array}{l}\text { Percentage of } \\
\text { baseline CRP at } \\
8 \text { weeks } * *\end{array}$ \\
\hline Placebo & 13 & $1.58(1.19,2.09)$ & $1.62(1.00,2.09)$ & $103(72,163)$ \\
\hline B vitamins & 12 & $1.75(1.06,2.75)$ & $1.84(0.93,2.62)$ & $105(82,150)$ \\
\hline Antioxidants & 13 & $1.90(1.16,2.29)$ & $1.64(1.12,2.11)$ & $86(88,122)$ \\
\hline $\mathrm{B}+$ Antioxidants & 14 & $2.03(1.36,3.05)$ & $2.39(1.42,4.62)$ & $118(75,171)$ \\
\hline
\end{tabular}

Geometric mean (interquartile range)

$* p=0.10$ for differences in percentage of baseline CRP between the four groups after 8 weeks. One-way ANOVA

$* * p=0.64$ for differences in percentage of baseline CRP between the four groups after 8 weeks. One-way ANOVA 
Table 5 Comparison of baseline ADMA and CRP (excludes subjects with CRP $>10 \mathrm{mg} / \mathrm{L}$ ) concentrations by smoking status

\begin{tabular}{llll}
\hline & Smokers & Non smokers & $p$ value \\
\hline ADMA $(\mu \mathrm{mol} / \mathrm{L})$ & $n=25$ & $n=75$ & \\
& $0.96(0.77,1.08)$ & $0.81(0.72,0.99)$ & 0.01 \\
\hline CRP $(\mathrm{mg} / \mathrm{L})$ & $n=23$ & $n=73$ & \\
& $1.26(0.91,1.48)$ & $1.22(0.85,1.54)$ & 0.85 \\
\hline
\end{tabular}

Geometric mean (interquartile range)

Smokers compared to non-smokers using independent samples $t$ test

$(<0.4 \mu \mathrm{mol} / \mathrm{L})$; [41] for CRP (data not shown). However, when the change in either ADMA or CRP was compared by the above nutrients within each intervention group, there were no significant effect of supplementation found
( $p=0.154$ for change in ADMA for those with initially low folate; $p=0.064$ for change in ADMA for those with initially low vitamin $\mathrm{C} ; p=0.233$ for change in ADMA for those with initially low $\alpha$-carotene; and $p=0.920$ for change in CRP for those with initially low $\beta$-carotene).

Baseline ADMA, but not CRP concentrations differed significantly between smokers and non-smokers $(p=0.01$ and $p=0.85$, respectively) (Table 5), with smokers having higher ADMA levels. Response to B vitamin and/or antioxidant supplementation was examined according to smoking status (Table 6). When the percentage of baseline ADMA and CRP was examined at 8 weeks, no statistically significant differences were observed between the four groups, for either smokers $(p=0.26$ and $p=0.40$, respectively) or non-smokers $(p=0.48$ and $p=0.92$, respectively).

Table 6 Percentage of baseline plasma ADMA and CRP (excludes subjects with CRP $>10 \mathrm{mg} / \mathrm{L}$ ) concentrations after 8 weeks of intervention (stratified by smoking status)

\begin{tabular}{|c|c|c|c|c|}
\hline $\begin{array}{l}\text { Intervention } \\
\text { group }\end{array}$ & Smokers $(n)$ & $\begin{array}{l}\text { Baseline } \\
\text { ADMA } \\
(\mu \mathrm{mol} / \mathrm{L})\end{array}$ & $\begin{array}{l}\text { Post-intervention } \\
\text { ADMA } \\
(\mu \mathrm{mol} / \mathrm{L})\end{array}$ & $\begin{array}{l}\text { Percentage of baseline } \\
\text { ADMA at } 8 \text { weeks* }\end{array}$ \\
\hline Placebo & 7 & $0.89(0.70,1.06)$ & $0.90(0.73,1.08)$ & $101(95,105)$ \\
\hline B vitamins & 6 & $0.94(0.79,1.14)$ & $0.98(0.86,1.14)$ & $104(95,113)$ \\
\hline Antioxidants & 4 & $1.04(0.83,1.35)$ & $0.84(0.63,1.20)$ & $80(66,95)$ \\
\hline \multirow[t]{2}{*}{$\mathrm{B}+$ antioxidants } & 8 & $1.01(0.76,1.09)$ & $1.00(0.83,1.12)$ & $99(84,133)$ \\
\hline & Non smokers $(n)$ & $\begin{array}{l}\text { Baseline } \\
\text { ADMA } \\
(\mu \mathrm{mol} / \mathrm{L})\end{array}$ & $\begin{array}{l}\text { Post-intervention } \\
\text { ADMA } \\
(\mu \mathrm{mol} / \mathrm{L})\end{array}$ & $\begin{array}{l}\text { Percentage of baseline } \\
\text { ADMA at } 8 \text { weeks** }\end{array}$ \\
\hline Placebo & 19 & $0.89(0.77,1.04)$ & $0.86(0.75,0.98)$ & $96(92,102)$ \\
\hline B vitamins & 16 & $0.82(0.74,0.96)$ & $0.83(0.77,1.00)$ & $102(93,107)$ \\
\hline Antioxidants & 18 & $0.74(0.55,1.04)$ & $0.70(0.54,0.95)$ & $95(77,108)$ \\
\hline \multirow[t]{2}{*}{$\mathrm{B}+$ antioxidants } & 17 & $0.80(0.65,1.02)$ & $0.82(0.61,1.04)$ & $103(92,108)$ \\
\hline & Smokers $(n)$ & $\begin{array}{l}\text { Baseline } \\
\text { CRP }(\mathrm{mg} / \mathrm{L})\end{array}$ & $\begin{array}{l}\text { Post-intervention } \\
\text { CRP (mg/L) }\end{array}$ & $\begin{array}{l}\text { Percentage of baseline } \\
\text { CRP at } 8 \text { weeks }{ }^{\dagger}\end{array}$ \\
\hline Placebo & 7 & $1.00(0.70,1.48)$ & $1.09(0.87,1.39)$ & $109(91,136)$ \\
\hline B vitamins & 6 & $1.58(1.10,2.92)$ & $1.51(0.96,2.28)$ & $96(78,117)$ \\
\hline Antioxidants & 3 & $0.98(0.91,1.09)$ & $1.71(0.86,3.19)$ & $174(89,294)$ \\
\hline \multirow[t]{2}{*}{$\mathrm{B}+$ antioxidants } & 7 & $1.45(0.83,1.62)$ & $1.79(0.95,4.32)$ & $123(81,137)$ \\
\hline & Non smokers $(n)$ & $\begin{array}{l}\text { Baseline } \\
\text { CRP }(\mathrm{mg} / \mathrm{L})\end{array}$ & $\begin{array}{l}\text { Post-intervention } \\
\text { CRP }(\mathrm{mg} / \mathrm{L})\end{array}$ & $\begin{array}{l}\text { Percentage of baseline } \\
\text { CRP at } 8 \text { weeks }\end{array}$ \\
\hline Placebo & 19 & $1.15(0.81,1.38)$ & $1.27(0.85,1.93)$ & $111(92,151)$ \\
\hline B vitamins & 14 & $1.01(0.84,1.32)$ & $1.07(0.74,1.50)$ & $108(81,124)$ \\
\hline Antioxidants & 20 & $1.44(0.95,1.81)$ & $1.46(1.02,1.94)$ & $102(93,128)$ \\
\hline $\mathrm{B}+$ antioxidants & 20 & $1.27(0.78,1.91)$ & $1.44(0.90,1.99)$ & $113(92,143)$ \\
\hline
\end{tabular}

Geometric mean (interquartile range)

$* p=0.26$ for differences in percentage of baseline ADMA between the four groups after 8 weeks. One-way ANOVA

$* * p=0.48$ for differences in percentage of baseline ADMA between the four groups after 8 weeks. One-way ANOVA

${ }^{\dagger} p=0.40$ for differences in percentage of baseline CRP between the four groups after 8 weeks. One-way ANOVA

* $p=0.92$ for differences in percentage of baseline CRP between the four groups after 8 weeks. One-way ANOVA 


\section{Discussion}

This analysis has found that supplementation with moderate doses of B vitamins and/or antioxidants for 8 weeks had no significant effect on ADMA or CRP concentrations in middle-aged, apparently healthy men with mildly elevated tHcy levels. Additionally, no effect of intervention was observed when the analysis was stratified by baseline CRP status or smoking status.

To date, only two studies have been carried out to examine the effect of antioxidants alone on ADMA levels in humans. Saran et al. demonstrated that supplementation with vitamin $\mathrm{E}(800 \mathrm{IU} / \mathrm{d})$ for 8 weeks may have the potential to lower ADMA concentrations in patients with chronic kidney disease (lowering effect seen in six out of eight patients) [42]; while Nanayakkara et al. [43] found that when separate treatment effects were examined in a multiple intervention design, vitamin E $(300 \mathrm{mg} / \mathrm{d})$ significantly decreased ADMA levels by $4 \%$ compared with the placebo group. However, the former study was an open-label, small-scale pilot study [42] and the latter a secondary analysis where mean plasma ADMA levels were relatively low at baseline $(0.53 \mu \mathrm{mol} / \mathrm{L})$ [43]. Therefore, these results should be treated with caution and warrant further investigation.

tHcy-induced endothelial dysfunction may result in increased synthesis of ADMA [11]. Folic acid and vitamin $\mathrm{B}_{12}$ decrease tHcy concentrations by stimulating remethylation into methionine, and vitamin $\mathrm{B}_{6}$ stimulates the breakdown of tHcy into cysteine through the transsulfuration pathway. Therefore, a possible lowering effect of tHcy with $\mathrm{B}$ vitamins may also lead to a reduction in ADMA concentrations. However, even though it has been shown that B vitamin supplementation leads to a significant decrease in tHcy concentrations [13], no effect has been reported on ADMA levels [44-47], with only one study showing an effect of $B$ vitamin supplementation on lowering ADMA levels in human subjects [48]. This study was a relatively small-scale study $(n=42)$, uncontrolled, with no placebo group and suffers from the design weaknesses associated with this type of intervention. The lack of statistically significant results from human intervention trials is backed up by a randomised, double-blind, placebo-controlled intervention using a combined B vitamin and antioxidant supplement [44], and also the current study. It is therefore highly unlikely that $B$ vitamins can lower ADMA, with Schmitt et al. actually suggesting a mechanism whereby $\mathrm{B}$ vitamin supplementation might even promote ADMA generation through increasing metabolic flux through the trans-sulphuration and remethylation pathways [44].

Associations between antioxidant vitamins and CRP concentrations have been reported in some $[49,50]$, but not in all epidemiological studies [51, 52]. Intervention studies have tried to clarify these ambiguous results; but these have also been inconclusive. Of those looking at the effects of vitamin $\mathrm{E}$, three studies found statistically significant treatment effects [18-20]; and four found no treatment effect [24-27]. Most of these studies were conducted in disease state subjects, especially those which reported an effect, unlike the apparently healthy men with mildly elevated tHcy levels used in the current study; healthy subjects were also used in three of the four studies reporting no effect [24, 25, 27]. Additionally, those which reported an effect often used doses of vitamin $E$ that were higher than those employed in the current study (e.g. $200 \mathrm{mg} / \mathrm{d}$ [18], $800 \mathrm{IU} / \mathrm{d}$ [19] and 1,200 IU/d [20]). With regard to vitamin $\mathrm{C}$, three studies found statistically significant treatment effects [21-23], and two found no treatment effect [28, 29]. Firm conclusions are difficult to draw from these studies due to the wide variation in doses used and the differing lengths of each intervention. Two studies have examined combined vitamin $\mathrm{C}$ and $\mathrm{E}$ supplementation [22, 30], but neither of these studies found significant reductions in CRP levels.

The three studies [21-23] that reported an effect of vitamin $\mathrm{C}$ on CRP levels were the only studies of either vitamin $\mathrm{C}$ or $\mathrm{E}$ to exclude subjects with $\mathrm{CRP}>10 \mathrm{mg} / \mathrm{L}$, as these subjects are likely to have acute infection or inflammatory disease [15]. It would also seem logical to hypothesise that biomarkers such as CRP would be more likely to be reduced when initially elevated. Therefore, two of three studies above [21, 23] also conducted stratified analysis by baseline CRP above and below $1.0 \mathrm{mg} / \mathrm{L}$. Both studies reported no treatment effect in those subjects with initially low CRP levels, CRP $<1.0 \mathrm{mg} / \mathrm{L}$, but a significant effect in those with initially higher levels. However, we found no effect of treatment even when the analysis was stratified by baseline CRP.

Few epidemiological studies have looked at B vitamins in relation to CRP levels, and, again, results have not been consistent [49, 51, 52]. Intervention studies carried out evaluating the effect of $\mathrm{B}$ vitamins on CRP concentrations have been conducted in subjects who were undergoing haemodialysis [53], or stable coronary artery disease patients [54], or those with hyperhomocysteinemia [55]. Two out of three reported no significant treatment effect on CRP levels [54, 55]. However, Chang et al. demonstrated that a 3-month intervention with a combined B vitamin supplement effectively lowered tHcy and CRP concentrations in haemodialysis subjects, although this study was a randomised, open-labelled study which used doses higher than those in this current study (folic acid $(5 \mathrm{mg} / \mathrm{d}$ ) and vitamin B complex) [53].

It was hypothesised that smokers might respond more strongly to the intervention, because smoking is associated 
with oxidative damage leading to lipid peroxidation and endothelial dysfunction [56]. Inflammatory changes may increase turnover of micronutrients so that blood concentrations are lower in smokers than non-smokers [57]. Unlike the majority of previous studies such as [58, 59], we did not see significantly higher baseline CRP levels among smokers within this study; although a current meta-analysis should confirm the relationship between smoking status and CRP [60], as results have not always been consistent [61]. However, we did show that smokers had significantly higher baseline ADMA levels than non-smokers within this population, which has been previously reported in some [62-64], although not all [65, 66] studies. When the analysis (percentage of baseline ADMA and CRP at 8 weeks) was stratified by smoking status, we observed no statistically significant differences between the four groups in response to supplementation. However, it should be noted that the number of subjects in this sub-group analysis was very small and these were exploratory analyses as the study was not originally powered for such stratification.

There are limitations to the current study. This study was a small-scale intervention study of apparently healthy men in Northern Ireland with only mildly elevated tHcy levels, involving a short supplementation period of 8 weeks. Additionally, this intervention was originally designed to test the effect of $\mathrm{B}$ vitamins and antioxidant vitamins on tHcy concentrations and, therefore, the secondary analyses presented in this paper may lack power and some of the robustness of larger, more specifically designed intervention studies. Comparing the result of this study with others is difficult due to the differences in the following: (1) the specific populations studied (ranging from healthy volunteers through to haemodialysis patients and diabetics); (2) the duration of the intervention period; (3) the combinations of micronutrients used; and (4) the doses of micronutrients used. These factors could all have had an influence on the findings of each individual study. For example, Block et al. [21] used 1,000 mg/d vitamin C and $800 \mathrm{IU} / \mathrm{d}(536 \mathrm{mg} / \mathrm{d})$ vitamin $E$ whereas we used a combination of $150 \mathrm{mg} / \mathrm{d}$ vitamin $\mathrm{C}$ and $67 \mathrm{mg} / \mathrm{d}$ vitamin $\mathrm{E}$ and also included $\beta$-carotene $(9 \mathrm{mg} / \mathrm{d})$. None of the studies have examined the dosedependent effects of $\mathrm{B}$ vitamins or antioxidants on ADMA or CRP. In terms of the study population, our participants were apparently healthy, although they had mildly elevated tHcy levels (mean, 9.66 $\mu \mathrm{mol} / \mathrm{L}$ ), and had CRP levels which were already quite low at baseline (mean, $1.23 \mathrm{mg} / \mathrm{L}$ ); therefore, a lowering effect of supplementation may have been difficult to achieve.

In summary, we have shown that treatment with B vitamins or antioxidants, whether administered independently or combined, for 8 weeks in male subjects with mildly elevated tHcy levels had no effect on ADMA or CRP concentrations. Additionally, no effect of intervention was observed when analysis was stratified by baseline CRP levels or smoking status. Results from further intervention studies are needed to confirm our results, although future studies may be better to focus on individuals with initially elevated ADMA and CRP levels, where effects of intervention are more likely to be detected, as there may be a threshold concentration above which there is the potential for reduction in ADMA and CRP levels with micronutrient supplementation.

Acknowledgments We acknowledge the Department for Employment and Learning, Belfast for their grant support. Also the technical assistance of Caroline Mercer, Janet Lightbody, Trevor Linton, Drew McIlveen, Maureen McCourt, Geraldine O'Reilly, Kellie Byrne and Ishbel McMillan. We thank the patients for their cooperation, WR Jenkinson (Shorts Brothers Plc, Belfast) and Sandoz Nutrition Ltd (Berne, Switzerland) who supplied the vitamin preparations.

Conflict of interest The authors declare that they have no conflict of interest.

\section{References}

1. Lenzen H, Tsikas D, Boger RH (2006) Asymmetric dimethylarginine (ADMA) and the risk for coronary heart disease: the multicenter CARDIAC study. Eur J Clin Pharmacol 62(Suppl 13):45-49. doi:10.1016/j.ahj.2006.06.005

2. Schulze F, Lenzen H, Hanefeld C, Bartling A, Osterziel KJ, Goudeva L, et al. (2006) Asymmetric dimethylarginine is an independent risk factor for coronary heart disease: results from the multicenter coronary artery risk determination investigating the influence of ADMA concentration (CARDIAC) study. Am Heart J 152(3):493.e1-8. doi:10.1016/j.ahj.2006.06.005

3. Lu TM, Ding YA, Charng MJ, Lin SJ (2003) Asymmetrical dimethylarginine: a novel risk factor for coronary artery disease. Clin Cardiol 26(10):458-464. doi:10.1002/clc.4960261006

4. Szuba A, Podgorski M (2006) Asymmetric dimethylarginine (ADMA) a novel cardiovascular risk factor-evidence from epidemiological and prospective clinical trials. Pharmacol Rep 58 Suppl:16-20

5. Landmesser U, Hornig B, Drexler H (2004) Endothelial function: a critical determinant in atherosclerosis? Circulation 109(21 Suppl 1):II27-33. doi:10.1161/01.CIR.0000129501.88485.1f

6. Vallance P, Leiper J (2004) Cardiovascular biology of the asymmetric dimethylarginine: dimethylarginine dimethylaminohydrolase pathway. Arterioscler Thromb Vasc Biol 24(6):1023-1030. doi:10.1161/01.ATV.0000128897.54893.26

7. Tran CT, Leiper JM, Vallance P (2003) The DDAH/ADMA/NOS pathway. Atheroscler Suppl 4(4):33-40. doi:10.1016/S15675688(03)00032-1

8. Maas R (2005) Pharmacotherapies and their influence on asymmetric dimethylargine (ADMA). Vasc Med 10(Suppl 1):S49S57. doi:10.1177/1358836X0501000108

9. Boger RH, Sydow K, Borlak J, Thum T, Lenzen H, Schubert B et al (2000) LDL cholesterol upregulates synthesis of asymmetrical dimethylarginine in human endothelial cells: involvement of S-adenosylmethionine-dependent methyltransferases. Circ Res 87(2):99-105

10. Jiang JL, Li Ns NS, Li YJ, Deng HW (2002) Probucol preserves endothelial function by reduction of the endogenous nitric oxide 
synthase inhibitor level. Br J Pharmacol 135(5):1175-1182. doi: 10.1038/sj.bjp.0704563

11. Stuhlinger MC, Oka RK, Graf EE, Schmolzer I, Upson BM, Kapoor O et al (2003) Endothelial dysfunction induced by hyperhomocyst(e)inemia: role of asymmetric dimethylarginine. Circulation 108(8):933-938. doi:10.1161/01.CIR.0000085067. 55901.89

12. Boger RH, Lentz SR, Bode-Boger SM, Knapp HR, Haynes WG (2001) Elevation of asymmetrical dimethylarginine may mediate endothelial dysfunction during experimental hyperhomocyst(e)inaemia in humans. Clin Sci (Lond) 100(2):161-167

13. Woodside JV, Yarnell JW, McMaster D, Young IS, Harmon DL, McCrum EE et al (1998) Effect of B-group vitamins and antioxidant vitamins on hyperhomocysteinemia: a double-blind, randomized, factorial-design, controlled trial. Am J Clin Nutr 67(5):858-866

14. Packard RR, Libby P (2008) Inflammation in atherosclerosis: from vascular biology to biomarker discovery and risk prediction. Clin Chem 54(1):24-38. doi:10.1373/clinchem.2007.097360

15. Pearson TA, Mensah GA, Alexander RW, Anderson JL, Cannon RO 3rd, Criqui $M$ et al (2003) Markers of inflammation and cardiovascular disease: application to clinical and public health practice: a statement for healthcare professionals from the centers for disease control and prevention and the American heart association. Circulation 107(3):499-511. doi:10.1161/01.CIR.000005 2939.59093.45

16. de Maat MP, Trion A (2004) C-reactive protein as a risk factor versus risk marker. Curr Opin Lipidol 15(6):651-657

17. May A, Wang TJ (2007) Evaluating the role of biomarkers for cardiovascular risk prediction: focus on CRP, BNP and urinary microalbumin. Expert Rev Mol Diagn 7(6):793-804. doi:10. 1586/14737159.7.6.793

18. Leichtle A, Teupser D, Thiery J (2006) Alpha-tocopherol distribution in lipoproteins and anti-inflammatory effects differ between CHD-patients and healthy subjects. J Am Coll Nutr 25(5):420-428

19. Upritchard JE, Sutherland WH, Mann JI (2000) Effect of supplementation with tomato juice, vitamin $\mathrm{E}$, and vitamin $\mathrm{C}$ on LDL oxidation and products of inflammatory activity in type 2 diabetes. Diabetes Care 23(6):733-738. doi:0.2337/diacare.23.6. 733

20. Devaraj S, Jialal I (2000) Alpha tocopherol supplementation decreases serum C-reactive protein and monocyte interleukin-6 levels in normal volunteers and type 2 diabetic patients. Free Radic Biol Med 29(8):790-792. doi:10.1016/S0891-5849(00) 00420-2

21. Block G, Jensen CD, Dalvi TB, Norkus EP, Hudes M, Crawford $\mathrm{PB}$ et al (2009) Vitamin C treatment reduces elevated C-reactive protein. Free Radic Biol Med 46(1):70-77. doi:10.1016/j.free radbiomed.2008.09.030

22. Block G, Jensen C, Dietrich M, Norkus EP, Hudes M, Packer L (2004) Plasma C-reactive protein concentrations in active and passive smokers: influence of antioxidant supplementation. J Am Coll Nutr 23(2):141-147

23. Church TS, Earnest CP, Wood KA, Kampert JB (2003) Reduction of C-reactive protein levels through use of a multivitamin. Am J Med 115(9):702-707. doi:10.1016/j.amjmed.2003.08.024

24. Woollard KJ, Rayment SJ, Bevan R, Shaw JA, Lunec J, Griffiths HR (2006) Alpha-tocopherol supplementation does not affect monocyte endothelial adhesion or C-reactive protein levels but reduces soluble vascular adhesion molecule- 1 in the plasma of healthy subjects. Redox Rep 11(5):214-222. doi:10.1179/135 100006X116727

25. Vega-Lopez S, Kaul N, Devaraj S, Cai RY, German B, Jialal I (2004) Supplementation with omega3 polyunsaturated fatty acids and all-rac alpha-tocopherol alone and in combination failed to exert an anti-inflammatory effect in human volunteers. Metabolism 53(2):236-240. doi:10.1016/j.metabol.2003.09.012

26. Himmelfarb J, Kane J, McMonagle E, Zaltas E, Bobzin S, Boddupalli $S$ et al (2003) Alpha and gamma tocopherol metabolism in healthy subjects and patients with end-stage renal disease. Kidney Int 64(3):978-991. doi:10.1046/j.1523-1755.2003. 00151.x

27. Kaul N, Devaraj S, Grundy SM, Jialal I (2001) Failure to demonstrate a major anti-inflammatory effect with alpha tocopherol supplementation (400 IU/day) in normal subjects. Am J Cardiol 87(11):1320-1323. doi:10.1016/S0002-9149(01)01534-X

28. Fumeron C, Nguyen-Khoa T, Saltiel C, Kebede M, Buisson C, Drueke TB et al (2005) Effects of oral vitamin C supplementation on oxidative stress and inflammation status in haemodialysis patients. Nephrol Dial Transplant 20(9):1874-1879. doi: $10.1093 / \mathrm{ndt} / \mathrm{gfh} 928$

29. Lu Q, Bjorkhem I, Wretlind B, Diczfalusy U, Henriksson P, Freyschuss A (2005) Effect of ascorbic acid on microcirculation in patients with Type II diabetes: a randomized placebo-controlled cross-over study. Clin Sci (Lond) 108(6):507-513. doi: 10.1042/CS20040291

30. Bruunsgaard H, Poulsen HE, Pedersen BK, Nyyssonen K, Kaikkonen J, Salonen JT (2003) Long-term combined supplementations with alpha-tocopherol and vitamin $\mathrm{C}$ have no detectable anti-inflammatory effects in healthy men. J Nutr 133(4):1170-1173

31. van Aken BE, Jansen J, van Deventer SJ, Reitsma PH (2000) Elevated levels of homocysteine increase IL-6 production in monocytic Mono Mac 6 cells. Blood Coagul Fibrinolysis 11(2):159-164

32. Dalal S, Parkin SM, Homer-Vanniasinkam S, Nicolaou A (2003) Effect of homocysteine on cytokine production by human endothelial cells and monocytes. Ann Clin Biochem 40(Pt 5):534-541. doi: $10.1258 / 000456303322326452$

33. Vuilleumier JP, Keck E (1989) Fluorometric assay of vitamin C in biological materials using a centrifugal analyser with fluorescence attachment. J Micronut Analysis 5:25-34

34. Ubbink JB, Hayward Vermaak WJ, Bissbort S (1991) Rapid highperformance liquid chromatographic assay for total homocysteine levels in human serum. J Chromatogr 565(1-2):441-446. doi: 10.1016/0378-4347(91)80407-4

35. Catignani GL, Bieri JG, Driskell WJ (1983) Simultaneous determination of retinol and alpha-tocopherol in serum or plasma by liquid chromatography. Clin Chem 29:708-712

36. Thurnham DI, Smith E, Flora PS (1988) Concurrent liquidchromatographic assay of retinol, $\alpha$-tocopherol, $\beta$-carotene, $\alpha$-carotene, lycopene, and $\beta$-cryptoxanthin in plasma, with tocopherol acetate as internal standard. Clin Chem 34:377-378

37. Reynolds TM, Brain A (1992) A simple internally-standardised isocratic HPLC assay for vitamin B6 in human serum. J Liquid Chromatogr 15:897-914. doi:10.1080/10826079208018843

38. Teerlink T, Nijveldt RJ, de Jong S, van Leeuwen PA (2002) Determination of arginine, asymmetric dimethylarginine, and symmetric dimethylarginine in human plasma and other biological samples by high-performance liquid chromatography. Anal Biochem 303(2):131-137. doi:10.1006/abio.2001.5575

39. Gey KF, Moser UK, Jordan P, Stahelin HB, Eichholzer M, Ludin E (1993) Increased risk of cardiovascular disease at suboptimal plasma concentrations of essential antioxidants: an epidemiological update with special attention to carotene and vitamin $\mathrm{C}$. Am J Clin Nutr 57(5 Suppl):787S-797S

40. Department of Health (1991) Dietary reference values for food energy and nutrients for the United Kingdom. Report of the panel on dietary reference values of the committee on medical aspects of food policy. Report on heath and social subject's No. 41. HSMO, London 
41. Gey KF (1998) Vitamins E plus C and interacting conutrients required for optimal health. A critical and constructive review of epidemiology and supplementation data regarding cardiovascular disease and cancer. Biofactors 7(1-2):113-174

42. Saran R, Novak JE, Desai A, Abdulhayoglu E, Warren JS, Bustami R et al (2003) Impact of vitamin E on plasma asymmetric dimethylarginine (ADMA) in chronic kidney disease (CKD): a pilot study. Nephrol Dial Transplant 18(11):2415-2420

43. Nanayakkara PW, Kiefte-de Jong JC, ter Wee PM, Stehouwer CD, van Ittersum FJ, Olthof MR et al (2009) Randomized placebocontrolled trial assessing a treatment strategy consisting of pravastatin, vitamin $\mathrm{E}$, and homocysteine lowering on plasma asymmetric dimethylarginine concentration in mild to moderate CKD. Am J Kidney Dis 53(1):41-50. doi:10.1053/j.ajkd.2008.06. 016

44. Schmitt B, Wolters M, Kressel G, Hulsmann O, Strohle A, KuhnVelten WN et al (2007) Effects of combined supplementation with B vitamins and antioxidants on plasma levels of asymmetric dimethylarginine (ADMA) in subjects with elevated risk for cardiovascular disease. Atherosclerosis 193(1):168-176. doi: 10.1016/j.atherosclerosis.2006.06.007

45. Spoelstra-de Man AM, Teerlink T, Brouwer CB, Rauwerda JA, Stehouwer CD, Smulders YM (2006) No effect of B vitamins on ADMA levels in patients at increased cardiovascular risk. Clin Endocrinol 64(5):495-501. doi:10.1111/j.1365-2265.2006. 02497.x

46. Ziegler S, Mittermayer F, Plank C, Minar E, Wolzt M, Schernthaner GH (2005) Homocyst(e)ine-lowering therapy does not affect plasma asymmetrical dimethylarginine concentrations in patients with peripheral artery disease. J Clin Endocrinol Metab 90:2175-2178

47. Sydow K, Schwedhelm E, Arakawa N, Bode-Boger SM, Tsikas D, Hornig B et al (2003) ADMA and oxidative stress are responsible for endothelial dysfunction in hyperhomocyst(e) inemia: effects of L-arginine and B vitamins. Cardiovasc Res 57(1):244-252. doi:10.1016/S0008-6363(02)00617-X

48. Holven KB, Haugstad TS, Holm T, Aukrust P, Ose L, Nenseter MS (2003) Folic acid treatment reduces elevated plasma levels of asymmetric dimethylarginine in hyperhomocysteinaemic subjects. Br J Nutr 89(3):359-363. doi:10.1079/BJN2002779

49. van Herpen-Broekmans WM, Klopping-Ketelaars IA, Bots ML, Kluft C, Princen H, Hendriks HF et al (2004) Serum carotenoids and vitamins in relation to markers of endothelial function and inflammation. Eur J Epidemiol 19(10):915-921. doi:10.1007/ s10654-004-5760-z

50. Ford ES, Liu S, Mannino DM, Giles WH, Smith SJ (2003) C-reactive protein concentration and concentrations of blood vitamins, carotenoids, and selenium among United States adults. Eur J Clin Nutr 57(9):1157-1163. doi:10.1038/sj.ejcn.1601667

51. Bertran N, Camps J, Fernandez-Ballart J, Arija V, Ferre N, Tous $M$ et al (2005) Diet and lifestyle are associated with serum C-reactive protein concentrations in a population-based study. J Lab Clin Med 145(1):41-46. doi:10.1016/j.lab.2004.11.002

52. Fredrikson GN, Hedblad B, Nilsson JA, Alm R, Berglund G, Nilsson J (2004) Association between diet, lifestyle, metabolic cardiovascular risk factors, and plasma C-reactive protein levels. Metabolism 53(11):1436-1442. doi:10.1016/j.metabol.2004.06. 010

53. Chang TY, Chou KJ, Tseng CF, Chung HM, Fang HC, Hung YM et al (2007) Effects of folic acid and vitamin B complex on serum $\mathrm{C}$-reactive protein and albumin levels in stable hemodialysis patients. Curr Med Res Opin 23(8):1879-1886. doi:10.1185/ $030079907 X 218077$

54. Bleie O, Semb AG, Grundt H, Nordrehaug JE, Vollset SE, Ueland PM et al (2007) Homocysteine-lowering therapy does not affect inflammatory markers of atherosclerosis in patients with stable coronary artery disease. J Intern Med 262(2):244-253. doi: 10.1111/j.1365-2796.2007.01810.x

55. Klerk M, Durga J, Schouten EG, Kluft C, Kok FJ, Verhoef P (2005) No effect of folic acid supplementation in the course of 1 year on haemostasis markers and C-reactive protein in older adults. Thromb Haemost 94(1):96-100. doi:10.1160/TH04-08-0524

56. Bakhru A, Erlinger TP (2005) Smoking cessation and cardiovascular disease risk factors: results from the Third National Health and Nutrition Examination Survey. PLoS Med 2(6):e160. doi:10.1371/journal.pmed.0020160

57. Northrop-Clewes CA, Thurnham DI (2007) Monitoring micronutrients in cigarette smokers. Clin Chim Acta 377(1-2):14-38. doi:10.1016/j.cca.2006.08.028

58. Wannamethee SG, Lowe GD, Shaper AG, Rumley A, Lennon L, Whincup PH (2005) Associations between cigarette smoking, pipe/cigar smoking, and smoking cessation, and haemostatic and inflammatory markers for cardiovascular disease. Eur Heart $\mathbf{J}$ 26(17):1765-1773. doi:10.1093/eurheartj/ehi183

59. Danesh J, Wheeler JG, Hirschfield GM, Eda S, Eiriksdottir G, Rumley A et al (2004) C-reactive protein and other circulating markers of inflammation in the prediction of coronary heart disease. N Engl J Med 350(14):1387-1397

60. Emerging Risk Factors Collaboration, Danesh J, Erqou S, Walker M, Thompson SG, Tipping R, et al. (2007) The emerging risk factors collaboration: analysis of individual data on lipid, inflammatory and other markers in over 1.1 million participants in 104 prospective studies of cardiovascular diseases. Eur J Epidemiol 22(12):839-869. doi: 10.1007/s10654-007-9165-7

61. Helmersson J, Larsson A, Vessby B, Basu S (2005) Active smoking and a history of smoking are associated with enhanced prostaglandin $\mathrm{F}$ (2alpha), interleukin-6 and F2-isoprostane formation in elderly men. Atherosclerosis 181(1):201-207. doi: 10.1016/j.atherosclerosis.2004.11.026

62. Zhang Z, Zou YY, Zhou Y, Zhou H, Li YJ (2009) The aggravatory effect of nicotine on Helicobacter pylori-induced gastric mucosa injury: role of asymmetric dimethylarginine. J Clin Gastroenterol 43(3):261-266. doi:10.1097/MCG.0b013e31816 24485

63. Schnabel R, Blankenberg S, Lubos E, Lackner KJ, Rupprecht HJ, Espinola-Klein C et al (2005) Asymmetric dimethylarginine and the risk of cardiovascular events and death in patients with coronary artery disease: results from the AtheroGene study. Circ Res 97(5):e53-e59. doi:10.1161/01.RES.0000181286.44222.61

64. Zhang WZ, Venardos K, Chin-Dusting J, Kaye DM (2006) Adverse effects of cigarette smoke on NO bioavailability: role of arginine metabolism and oxidative stress. Hypertension 48(2):278-285. doi:10.1161/01.HYP.0000231509.27406.42

65. Sobczak A, Goniewicz ML, Szoltysek-Boldys I (2009) ADMA and SDMA levels in healthy men exposed to tobacco smoke. Atherosclerosis 205(2):357-359. doi:10.1016/j.atherosclerosis. 2008.12.039

66. Onat A, Hergenc G, Can G, Karabulut A (2008) Serum asymmetric dimethylarginine levels among Turks: association with metabolic syndrome in women and tendency to decrease in smokers. Turk Kardiyol Dern Ars 36(1):7-13 